\title{
屋上緑化利用水の水質調査および細菌リスク評価 \\ WATER QUALITY SURVEY AND BACTERIA RISK ASSESSMENT \\ OF THE ROOF REPLANTING UTILIZATION WATER
}

\author{
中村伸也*, 野知啓子**, 大塚 雅 之*** \\ 山海敏弘 $* * * *$, 武田 仁*****, 中島 古史郎****** \\ Shinya NAKAMURA, Keiko NOCHI, Masayuki OTSUKA, \\ Toshihiro SANKAI, Hitoshi TAKEDA and Koshirou NAKAJIMA
}

In this study, the roof replanting system was made to circulate water supply, and the water analysis was carried out in recycling retention type roof replanting system, and the tendency in the water quality by cyclic use was confirmed. And, water quality evaluation with the reuse water in carrying out water analysis on circulation bathtub water for ordinary homes and ordinary homes bathtub water and purifying chamber treated water, scene water with the room examined as a reuse application water in future, and ranking as water for miscellaneous use was carried out in addition to the rain water which the examination had already advanced in making the reuse water to use application such as the roof replanting system. In addition, these water qualities in order to grasp whether it has the risk in which degree is bacteriological, the bacteria which can proliferate in various application water were measured, and the hygienic safety from bacterial growth ability of the water was evaluated.

Keywords : Roof replanting, rain water and reuse water, resources recycling system, water quality survey, bacterial contamination, bacterial infection risk.

屋上緑化、雨水·再利用水、資源循環システム、水質調査、細菌污染、細菌感染症リスク

1. はじめに

都市空間全体を冷却し、ヒートアイランド現象を緩和する技術と して屋上緑化システムが注目されている。本システムは、ヒートア イランド対策以外にも冷暖房負荷の軽減化および大気污染防止など、 多方面においてその効果が期待されている。今後、本システムが普 及していくには、軽量で保水性の高い土壌材の改良、薄層地盤に適 し、乾燥にも強い植栽の育種、潅水システム方法、そしてガーデニ ングとしてのアメニティ要素等、さらなる技術開発が要求されてい る。とくに緑化植物の維持に必要である水利用方法については、節 水や水の有効利用を促進させるために、上水以外の雑用水を二次利 用することも考案されている。

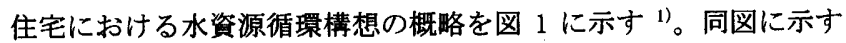
とおり、本住宅は生活系排水を処理し、雑用水として二次利用し、 住宅内において水を循環し再利用することを試みている。

一方、これら再利用水を屋上緑化利用水とするには、細菌感染症 へのリスクを考虜した衛生学的に安全性の高い利用方法が必須条件 である。特に貯留槽を設置し、循環系で行う水使用形態はレジオネ ラ感染症(第四型呼吸器感染症)のリスクが高い施設になってくる ${ }^{2)}$ 。
これら、レジオネラ症に対する行政的指導としては、2003 年 7 月 25 日に厚生労働省告示第 264 号「レジオネラ症を予防するために必 要な措置に関する技術上の指針」が制定され、「感染症の予防の総合 的な推進を図るための基本的な指針」（2001 年 4 月 1 日）を補足す るものとして具体的な指導が行われている ${ }^{3)}$ 。これは感染症が多発 している入浴施設を対象としたものであるが、海外で多く発症して いる冷却塔等およびエアロゾルを発生させるその他の設備も対象と なっている。すなわち、建物内における人工水の衛生管理は管理責 任を持つ施設側にあるため、緑化利用水の安全性管理も含め設備系 統の適正管理の重要性はさらに高まっている。

以上の背景から本研究では、屋上緑化システムにおける利用水の 循環利用を念頭におき、まず屋上緑化利用水の水質実態調查を行い、 細菌污染状況を把握し、衛生学的な視点から使用実態を明らかにし た。さらに各種用途水の屋上緑化利用水としての可能性を探るため に、細菌リスク評価を含めた水質評価を行い、今後におけるこれら 施設の衛生管理手法を確立するための基礎資料を得ることを目的と した。
$*$ 関東学院大学大学院博士前期課程工学研究科 大学院生

** 関東学院大学工学部社会環境システム学科 技師・工博

****関東学院大学工学部建築学科 教授. 工博

*****独立行政法人建築研究所上席研究員

***** 東京理科大学 教授 $\cdot$ 工博

******* 積水化学工業環境・ライフカンパニー開発部
Graduate Student, Graduate School of Engineering, Kanto-Gakuin Univ.

Eng., Dept. of Civil and Environmental Engineering, Kanto-Gakuin Univ., Dr. Eng. Prof., Dept. of Architecture Kanto-Gakuin Univ., Dr. Eng. Building Research Institute

Prof., Tokyo University of Science, Dr. Eng.

Chief Engineer, Sekisui Chemical Co., Ltd. 


\section{2. 实硂方法}

\section{1 屋上緑化利用水の水䨘的查}

屋上緑化利用水の調查は、すでに設置されている屋上緑化施設を 対象とした。各施設の概要を表 1 に示す。A 大学構内にある屋上緑 化実験施設 $(n=6) 、 B$ 研究所内にある屋上緑化実験施設 $(n=2) 、 C$ 研 究所屋上緑化実験施設 $(\mathrm{n}=1) 、 \mathrm{D}$ 住宅展示場屋上に設置された屋上 緑化実験施設 $(\mathrm{n}=1) 、 \mathrm{E}$ 役所および $\mathrm{F}$ 役所屋上に設置された屋上緑 化施設 $(n=1)$ 計 6 施設の眝留水槽内の水質について実態調查を行 った。同表に示すとおり 6 箅所の屋上緑化システムのうち、B 屋上 緑化実験施設は平面パネル式緑化パレットシステム、その他の施設 については底面腯水式緑化システムとなっている。一例として写真 1 に F 屋上緑化施設を示す。

平面パネル式緑化パレットシステムは、傾斜屋根に緑化パレット を設㯰し、棟部の染み出しホースより潅水し、軒先まで浸透した余 剩水は雨桶より回収する方式を仕様としている。

一方、底面海水方式緑化システムは植栽パレットの下面から散水 し、貯留タンクよりポンプで植栽パレット下部に所定時間給水・— 時滞留し、土壤の毛細管現象で潅水後、再び眝留タンクへ戻す。雨 水は植栽パレット面で回収し、不足時には上水（中水）を補給する システムとなっている。

緑化システムの概況は、散水頻度が 1 日 1 回、散水量は 30〜45 $\mathrm{m}^{2}$ 程度、システムの土壤厚は $20 \sim 70 \mathrm{~mm}$ 、貯留槽に市販の遮光精度 $80 \%$ のシートを被覆させ遮光措置を行っていた。システムの経過年 は 7 ヶ月のものから、2 年経過しているものもあった。上水の補給 については、ボールタップによる自動給水方式をとっているものが 多く、植栽に対する肥料については、システム設置時に腐葉土を施 肥している。

屋上緑化利用水の水質測定項目は外観、透視度、 $\mathrm{p} \mathrm{H}$ 、電気伝導 率、臭気、TOC、COD、㦟濁物質、一般細菌、従属栄荃細菌、レジ オネラ属菌および大腸菌群について行い、試験方法は上水試験方法 ${ }^{4)}$ に基づいた。

\section{2 各種用途水の水䨢喟查}

本実験では、雨水、一般家庭浴槽水、合併式浄化槽処理水、修景 用水および循棵浴槽水を対象とした。表 2 に各種用途水の調查概要 を示す5)。

本実験で対象とした家庭用合併式浄化槽は、ディスポーザ対応型 浄化槽であり、第一嫌気ろ床槽、第二嫌気ろ床槽からなり、処理水 は第一嫌気ろ床槽一の循環により、窒素除去が行われる。生物ろ過 槽は上段が反応部、下段がろ過槽に区切られ、 $1 \mathrm{~mm}$ 角の担体が充填 されている。上段底部には散気管が取り付けられ、常時ばっ気が行 われ、担体に付着した微生物により排水は酸化分解される。対象と した処理水は、この生物ろ過槽後段で採取した。

一般浴槽水の入浴条件は入浴者が 8 人であり、入浴後、浴槽 (FRP 製）容量約 $220 \mathrm{~L}$ 中から $3 \mathrm{~L}$ の浴槽水を採取した。試料の採取時間は 入浴後 12 時間以内に行った。

雨水は 2003 年 6 月 25 日〜 11 月 25 日の間に計 6 回採取した。雨 水の採取は、6月 22 日〜 2 月 25 日（RUN1）、6月 26 日〜 7 月 1 日 (RUN2)、7月 7 日〜 7 10 日（RUN3）に行った。なお、11月 21 日（RUN4）と 11 月 25 日（RUN5）は、関東学院大学実験棟の

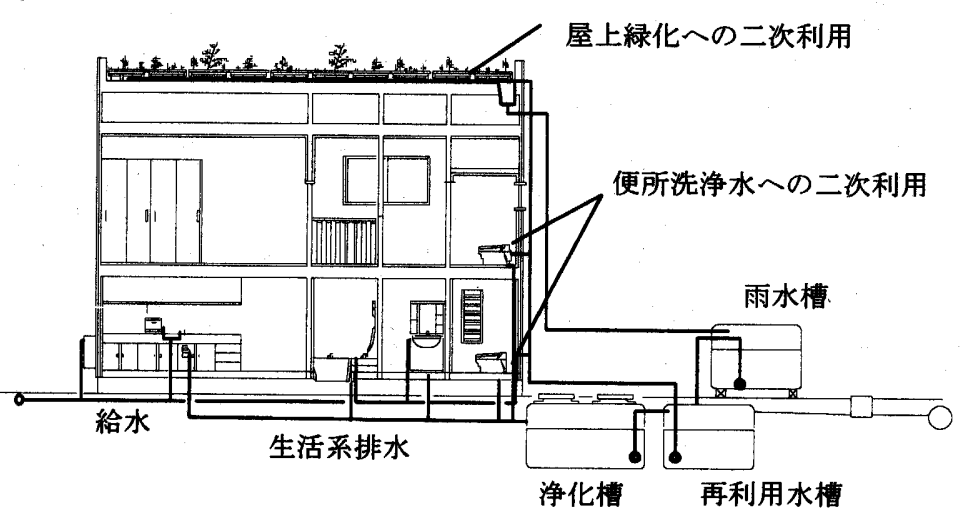

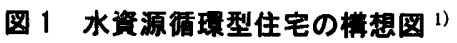

表 1 调查対象とした屠上緑化システムの概要 $(n=1 \sim 9)$

\begin{tabular}{|c|c|c|c|c|c|c|}
\hline \multirow{2}{*}{\begin{tabular}{|c} 
屋上緑化 \\
施設
\end{tabular}} & \multirow{2}{*}{ 所在地 } & \multirow{2}{*}{ 給水系統 } & \multirow{2}{*}{$\begin{array}{c}\text { 賍留水樯 } \\
\text { 容量 }\end{array}$} & \multicolumn{2}{|c|}{ 植截パレット } & \multirow{2}{*}{ 採水日 } \\
\hline & & & & 榲栽種類 & 面稹 $\left(\mathrm{m}^{2}\right)$ & \\
\hline$A$ 実銅施設 & 千葉県 & \begin{tabular}{|l} 
雨水·上水 \\
循環利用 \\
\end{tabular} & $500 \mathrm{~L}$ & 高瑟芝 & 3. 24 & $\begin{array}{c}2003.7 .28 \\
\sim 9.29\end{array}$ \\
\hline 実験施設 & 茨城罢 & 上水 & - & $\begin{array}{c}\text { セタムニ } \\
\text { ケ }\end{array}$ & 4. 86 & $\begin{array}{c}2003.9 .18 \\
\sim 12.4 \\
\end{array}$ \\
\hline C実験施設 & 京都府 & \begin{tabular}{|c|} 
雨水·上水 \\
循環利用 \\
\end{tabular} & $300 \mathrm{~L}$ & 高霓芝 & 3. 24 & 2003.9 .10 \\
\hline D緑化施設 & $\begin{array}{c}\text { 神奈川 } \\
\text { 県 } \\
\end{array}$ & $\begin{array}{l}\text { 雨水·上水 } \\
\text { 循環利用 } \\
\end{array}$ & $600 \mathrm{~L}$ & 高麗茫 & 15.12 & 2003.9. 30 \\
\hline |E緑化施設 $\mid$ & 埼玉県 & $\begin{array}{l}\text { 雨水·上水 } \\
\text { 循環利用 }\end{array}$ & $300 \mathrm{~L}$ & 高丽芝 & 3.6 & 2003.12 .2 \\
\hline F緑化施設 & 東京都 & $\begin{array}{l}\text { 雨水.上水 } \\
\text { 循澴利用 }\end{array}$ & $300 \mathrm{~L}$ & 高麗芝 & 3.6 & 2003.12 .2 \\
\hline
\end{tabular}

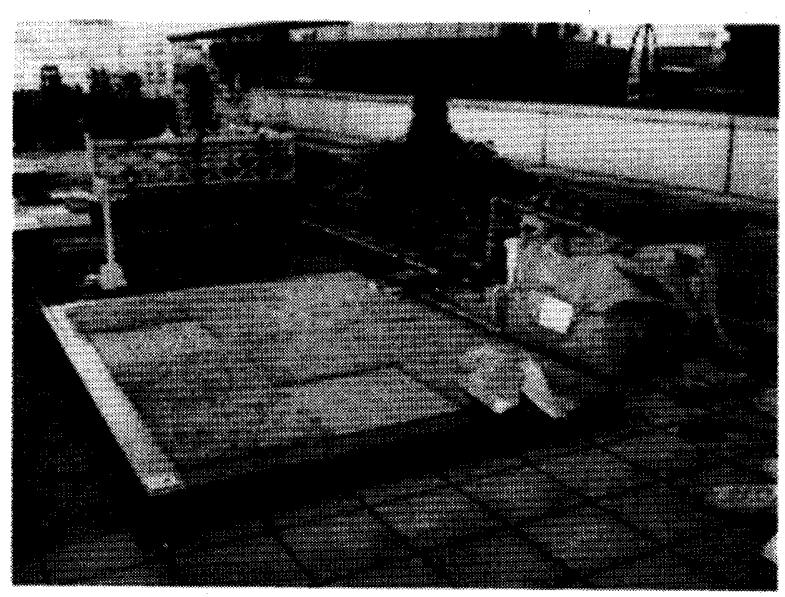

写車 1 F 屋上緑化施設

表 2 各種用途水の啁查概要

\begin{tabular}{|c|c|c|c|}
\hline 対象試料 & $\begin{array}{c}\text { 試料数 } \\
(\mathrm{n})\end{array}$ & 採水日 & 採取場所 \\
\hline 雨水 & 6 & $\begin{array}{c}2003.6 \text { 月 } \\
\sim 11 \text { 月 }\end{array}$ & $\begin{array}{c}\text { 関東学院大学 } \\
\text { 設偏工学研究所屋上 }\end{array}$ \\
\hline 一般家庭浴槽水 & 6 & $\begin{array}{c}2003.6 \text { 月 } \\
\sim 12 \text { 月 }\end{array}$ & A宅浴槽, B宅浴槽 \\
\hline 家庭用循環浴槽水 & 6 & $\begin{array}{c}2003.4 \text { 月 } \\
\sim 7 月\end{array}$ & C宅浴槽 \\
\hline 合併式浄化槽処理水 & 9 & $\begin{array}{c}2002.6 \text { 月 } \\
\sim 2003.5 \text { 月 }\end{array}$ & D研究所 \\
\hline 修景用水 & 6 & $2003.11 / 28$ & E動物園内遊水池 \\
\hline
\end{tabular}


東側に設置してある屋外喫煙所の片流れ屋根から、雨樋を流れる雨 水を容器に採取した。RUN1〜RUN5 は降雨直後の採取とした。さ らに、RUN6（11月 21 日）の試料は無蓋のポリバケツ容器に約半年 間、屋上環境下において静置の状態で長期滞留した雨水を採取した。 雨水採取時の気象状況を表 3 に示す。気象データは、気象庁横浜観 測所（緯度 : 35 度 26.3 分、経度 : 139 度 39.1 分、標高 : $39 \mathrm{~m}$ ) 閱 覧電子データをまとめたものである。主な気象状況としては、 RUN1 の採取時は平均気温 $23.0^{\circ} \mathrm{C}$ 、平均相対湿度 $80.7 \%$ 、平均風速 $2.6 \mathrm{~m} / \mathrm{s}$ および積算降水量 $37.0 \mathrm{~mm}$ となっている。RUN2 は平均気温 $22.6^{\circ} \mathrm{C}$ 、平均相対湿度 $77.0 \%$ 、平均風速 $2.6 \mathrm{~m} / \mathrm{s}$ および積算降水量 $12.5 \mathrm{~mm}$ であった。同様に RUN3 は $21.3^{\circ} \mathrm{C} 、 83.0 \% 、 3.1 \mathrm{~m} / \mathrm{s}$ および $12.0 \mathrm{~mm} 、 \mathrm{RUN} 4$ および RUN6 は $17.1^{\circ} \mathrm{C} 、 76 \% 、 3.0 \mathrm{~m} / \mathrm{s}$ および $9 \mathrm{~mm}$ であり、RUN5 は $11.4^{\circ} \mathrm{C} 、 83.0 \% 、 5.7 \mathrm{~m} / \mathrm{s}$ および $45 \mathrm{~mm}$ であった。

家庭用循環浴槽システムは、容量 $2.6 \mathrm{~L}$ の滤過槽が 2 系列設置され、 この中を浴槽水が循環することで生物浄化が進行する。また、紫外 線照射灯が付設しており、1 日 8 時間の照射となっている。試料は $230 \mathrm{~L}$ の浴槽内から入浴 8 時間後（入浴者 : 4 人）に採取した。

修景用水は 2003 年 11 月 28 日に、G 動物園の敷地内にある遊水 池（以下修景用水とする）の計 6 箇所から採取した。

\section{3 各種用途水の細菌リスク予測評価}

\subsection{1一般細菌の増殖試験}

本実験では、各種用途水における細菌のリスクを評価するために 一般細菌の増殖試験を行った。まず、合成基質試料（グルコース,グ ルタミン酸) の TOC (有機物) 灙度を 0 95.9mg/L の瀑度段階をと り、この中で増殖する一般細菌の増殖挙動を測定した。さらに、各 種用途水の TOC 濃度を実測し対比させることで、細菌増殖の主要素 である各種用途水の有機污濁物質濃度による一般細菌の増殖リスク を予測した。

実験方法は滅菌水にグルコース、グルタミン酸混合液を TOC 値と して 1.6〜95.9mg/L になるように添加する。これに継代培養した一 般細菌 1 白金耳を滅菌水で $10 \mathrm{~mL}$ とした調製液の中から $100 \mu \mathrm{L}$ 植 菌し、全量を $300 \mathrm{~mL}$ とする。これを $90 \mathrm{rpm} 、 25^{\circ} \mathrm{C}$ の条件下で 24 120 時間の振とう培羕試験を行った。

さらに各種用途水中における本細菌のリスク予測は各種用途水の 示すTOC 值に本菌がどの程度増殖するのかで評価した。

\section{3.2 レジオネラ属菌の増殖試験}

本実験では、各水質中におけるレジオネラ属菌の增殖特性からリ スク評価を行った。まず、振とう培養法による実験では、雨水、修 景用水、循環浴槽水、浄化槽処理水、精製水を孔径 $0.22 \mu \mathrm{m}$ でろ過 滅菌し、試料中に增殖している細菌類を除去し、300 $\mathrm{mL}$ を共栓付き 三角フラスコに分取する。この試料水中にWYO $\alpha$ レジオネラ選択培 地で培養したレジオネラ属菌を $10^{2} \mathrm{CFU} / \mathrm{mL}$ になるように植菌し、 $25^{\circ} \mathrm{C} 、 90 \mathrm{rpm}$ で振とう培養実験を行った。測定は培養前後における TOC およびレジオネラ属菌数とした。

次に恒温槽内における静置実験としては次のとおりに行った。

入浴後の一般浴槽水、家庭用循環浴槽水および修景用水、対照試 料として給湯水を用い、 $25^{\circ} \mathrm{C} 、$ 静置条件下におけるレジオネラ属菌 等の増殖特性について検討した。なお、本条件下ではろ過滅菌は行
表 3 雨水探取時における気象钼測值 (2003 年気象庁横浜锶測所)

\begin{tabular}{|l|c|c|c|c|c|c|c|}
\hline & $\begin{array}{c}\text { 平均 } \\
\text { 気圧 } \\
(\mathrm{hPa})\end{array}$ & $\begin{array}{c}\text { 平均 } \\
\text { 気温 } \\
\left({ }^{\circ} \mathrm{C}\right)\end{array}$ & $\begin{array}{c}\text { 最高 } \\
\text { 気温 } \\
\left({ }^{\circ} \mathrm{C}\right)\end{array}$ & $\begin{array}{c}\text { 最低 } \\
\text { 気温 } \\
\left({ }^{\circ} \mathrm{C}\right)\end{array}$ & $\begin{array}{c}\text { 平均相対 } \\
\text { 湿度 }(\%)\end{array}$ & $\begin{array}{c}\text { 平均 } \\
\text { 風速 } \\
(\mathrm{m} / \mathrm{s})\end{array}$ & $\begin{array}{c}\text { 積算 } \\
\text { 降水量 } \\
(\mathrm{mm})\end{array}$ \\
\hline RUN 1 & 1012 & 23 & 30.2 & 20.2 & 80.7 & 2.6 & 37 \\
\hline RUN 2 & 999.8 & 22.6 & 28.3 & 18.8 & 77 & 2.6 & 12.5 \\
\hline RUN 3 & 1007.4 & 21.3 & 24.9 & 18.4 & 83 & 3.1 & 12 \\
\hline RUN 4 & 997.1 & 17.1 & 23.1 & 10.9 & 76 & 3 & 9 \\
\hline RUN 5 & 1017 & 11.4 & 15.1 & 9 & 83 & 5.7 & 45 \\
\hline RUN 6 & 997.1 & 17.1 & 23.1 & 10.9 & 76 & 3 & 9 \\
\hline
\end{tabular}

\section{表 4 尿上緑化利用水の水躓特性}

\begin{tabular}{|c|c|c|c|c|c|c|}
\hline & \multicolumn{6}{|c|}{ 対象施設 } \\
\hline & A施設 & B施設 & C施設 & D施設 & E施設 & F施設 \\
\hline 外観 & $\begin{array}{l}\text { 微緑 } \\
\text { 黄色 }\end{array}$ & $\begin{array}{l}\text { 無色 } \\
\text { 透明 }\end{array}$ & 弱黄色 & 弱黄色 & 弱黄色 & 微黄色 \\
\hline 透視度 $(\mathrm{cm})$ & 45.8 & 50以上 & 50以上 & 36.5 & 50以上 & 50以上 \\
\hline $\mathrm{pH}(-)$ & 7.3 & 7.84 & 7.2 & 6.7 & 7.1 & 7.1 \\
\hline 奥気 & 弱藻奥 & 微弱 & 土奥 & 土奥 & 青草臭 & 土臭 \\
\hline $\begin{array}{l}\text { 電気伝導率 } \\
(\mu \mathrm{S} / \mathrm{cm})\end{array}$ & 150 & - & 154 & 78 & 70 & 134 \\
\hline DOC (mg/L) & 7.64 & - & 11.4 & 4.75 & 7.14 & 3.22 \\
\hline $\operatorname{COD}(\mathrm{mg} / \mathrm{L})$ & 9.54 & 3.65 & 12.0 & 10.5 & 9.04 & 3.11 \\
\hline $\mathrm{T}-\mathrm{N}(\mathrm{mg} / \mathrm{L})$ & 0.86 & 0.16 & 0.63 & 2.92 & 0.46 & 1.21 \\
\hline T-P (mg/L) & - & 0.06 & - & - & 0.15 & 0.06 \\
\hline SS (mg/L) & 7.26 & - & 0.89 & 8.22 & 3.90 & 1.80 \\
\hline $\begin{array}{l}\text { 一般細菌 } \\
(\mathrm{CFU} / \mathrm{mL}) \\
\end{array}$ & $\begin{array}{l}1.8 \\
\times 10^{3} \\
\end{array}$ & $\begin{array}{r}2.2 \\
\times 10^{3} \\
\end{array}$ & $\begin{array}{l}6.8 \\
\times 10^{2} \\
\end{array}$ & $\begin{array}{l}4.4 \\
\times 10^{3} \\
\end{array}$ & $\begin{array}{l}2.0 \\
\times 10^{4} \\
\end{array}$ & $\begin{array}{l}2.8 \\
\times 10^{3} \\
\end{array}$ \\
\hline $\begin{array}{c}\begin{array}{c}\text { 従属栄養細菌 } \\
(\mathrm{CFU} / \mathrm{mL})\end{array} \\
\end{array}$ & $\begin{array}{r}3.2 \\
\times 10^{4} \\
\end{array}$ & $\begin{array}{l}2.1 \\
\times 10^{5} \\
\end{array}$ & $\begin{array}{r}8.3 \\
\times 10^{3} \\
\end{array}$ & $\begin{array}{l}6.7 \\
\times 10^{4} \\
\end{array}$ & $\begin{array}{r}2.5 \\
\times 10^{5} \\
\end{array}$ & $\begin{array}{r}1.5 \\
\times 10^{5} \\
\end{array}$ \\
\hline 大腸菌群 (CFU/mL) & 62 & 15 & 8 & 3 & 1390 & 25 \\
\hline $\begin{array}{c}\text { レジオネラ属菌 } \\
\text { (CFU/100mL) }\end{array}$ & 355 & 58 & 440 & 130 & 220 & 100 \\
\hline
\end{tabular}

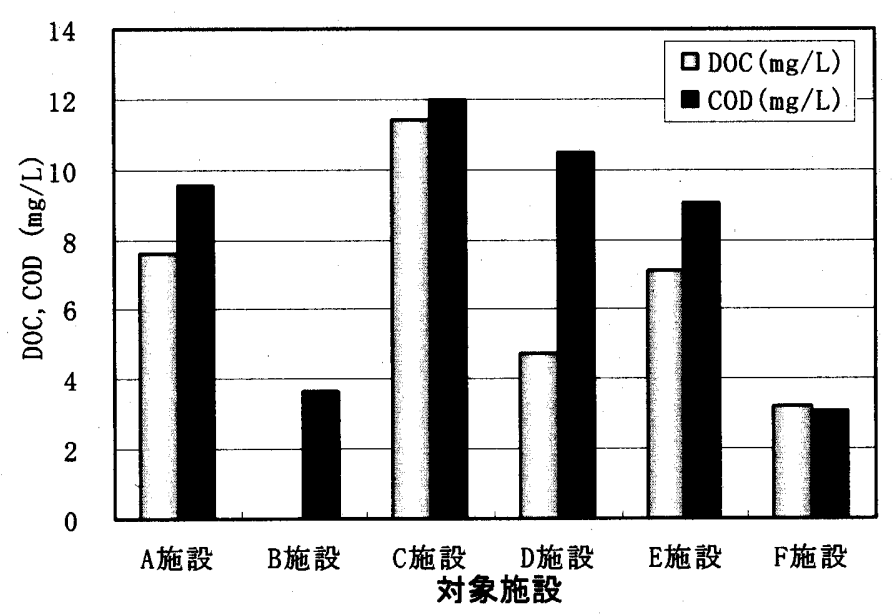

図 2 屋上緑化利用水中における DOC，COD 
わずに、レジオネラ属菌は無添加とし、すでに試料中に存在してい るレジオネラ属菌の増殖特性について検討した。

\section{3. 結果および考察}

\section{1 屋上緑化利用水の水貫特性}

屋上緑化利用水の 6 施設における水質特性を表 4 に示す。全体的 に各屋上緑化利用水は藻類の増殖が顕著であった。これは水質項目 の外観、透視度、臭気から評価された。各屋上緑化利用水の有機系 污濁状況を知るために COD および DOC (溶存有機炭素)を測定し、 図 2 に示す。

同図より、屋上緑化利用水の有機系污渴が最も進行している施設 は C 施設であり、COD および DOC は $11.4 \mathrm{mg} / \mathrm{L} 、 12.0 \mathrm{mg} / \mathrm{L}$ の高 い值を示した。調查対象とした 6 施設のうち、67\%の 4 施設 (A,C,D,E) において、COD が 9.04〜 12.0mg/L となった。そのう ち 3 施設（A,C,E）は DOC も 7.14〜11.4mg/L を示した。

一方、COD (10.5mg/L) に対し、極端に DOC が $4.75 \mathrm{mg} / \mathrm{L}$ と低 い D 施設の試料中には、ろ過することで除かれる藻類の存在があり、 $\mathrm{COD}$ は藻類も含み $100^{\circ} \mathrm{C}$ で募沸し測定する方法であるため、高い值 になったと考えられる。また、B 施設においては、水道からの直接 給水であり循環系の水質ではないことから、有機系污濁が進行して いないことが考えられた。

図 3 には屋上緑化利用水中から検出された一般細菌、従属栄養細 菌、大腸菌群およびレジオネラ属菌の検出数を示した。

従属栄養細菌は $10^{4} \mathrm{CFU} / \mathrm{mL} \sim 10^{5} \mathrm{CFU} / \mathrm{mL}$ オーダーで検出され、 一般細菌数も比較的高く $10^{2} \mathrm{CFU} / \mathrm{mL} \sim 10^{4} \mathrm{CFU} / \mathrm{mL}$ と細菌污染は顕 著であった。また、大腸菌群は $\mathrm{E}$ 施設において最大值で $1390 \mathrm{CFU} / \mathrm{mL}$ が検出された。一方、病原性細菌としてエアロゾルの飛散等による 感染症に注意が必要とされる、レジオネラ属菌は全施設で検出され た。検出されたレジオネラ属菌数は 58〜440CFU/100mL を示し、 浴場施設における指針値 $10 \mathrm{CFU} / 100 \mathrm{~mL}$ 未満（検出されないこと） より高い結果となった。

\section{2 各種用途水の水筫評価}

各種用途水の水質特性について、中央值でまとめたものを表 $\mathbf{5}$ に 示す。降雨直後における雨水の $\mathrm{pH}$ は 4.9 の酸性を示した。電気伝導 率は、26.6 $\mu \mathrm{S} / \mathrm{cm}$ であり、降雨直後の雨水中含有成分は低いことが わかる。同様に一般細菌数も 50CFU/mL と低い值となったが、従属 栄養細菌は $10^{5} \mathrm{CFU} / \mathrm{mL}$ 程度の高い値を示し、雨水中に従属栄美細 菌は増殖していることが示された。一方、RUN6 の長期滞留した雨 水について、降雨直後の雨水と比較すると、有機污濁物質 (TOC,DOC) に明らかな増加がみられ、それに伴い一般細菌数およ び従属栄盖細菌数についても、降雨直後の雨水に比べ $10 \sim 10^{2}$ 倍程 度高い検出数が確認された。また、レジオネラ属菌については 2.96 $\times 10^{4} \mathrm{CFU} / 100 \mathrm{~mL}$ 、大腸菌群についても同様に $240 \mathrm{CFU} / \mathrm{mL}$ が確認 された。この結果より雨水を長期放置・滞留しておくことで水質は 劣化し、それに伴って細菌は増殖していくことが示された。

一般浴槽水の水質特性をみると、TOC は $3.64 \mathrm{mg} / \mathrm{L}$ を示し、一般 細菌は $1200 \mathrm{CFU} / \mathrm{mL}$ および従属栄養細菌は $10^{5} \mathrm{CFU} / \mathrm{mL}$ の検出が確 認され、細菌污染は顕著であった。一方、循環浴槽水の TOC は 1.8 $\mathrm{mg} / \mathrm{L}$ と低く、生物灅過槽により処理された水質は安定していた。浄

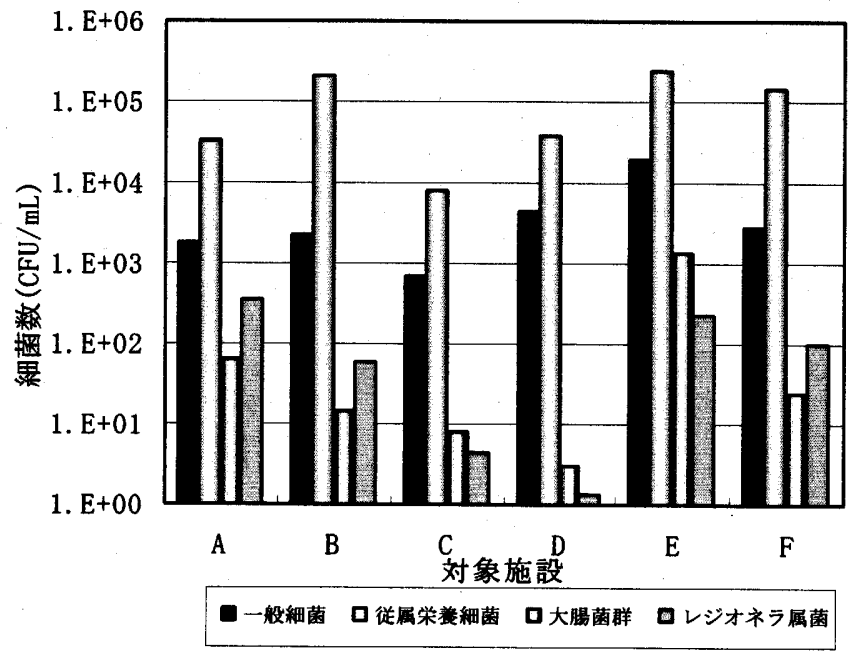

図 3 屋上緑化利用水中における細菌検出数

表 5 各種用途水の水貫特性（中央値 $n=6 \sim 9$ ）

\begin{tabular}{|c|c|c|c|c|c|}
\hline & $\begin{array}{l}\text { 雨水 } \\
\text { (RUN6) }\end{array}$ & \begin{tabular}{|c} 
一般浴槽 \\
水
\end{tabular} & $\begin{array}{l}\text { 循環 } \\
\text { 浴槽水 }\end{array}$ & $\begin{array}{l}\text { 浄化槽 } \\
\text { 処理水 }\end{array}$ & $\begin{array}{l}\text { 修景用 } \\
\text { 水 }\end{array}$ \\
\hline 外観 & $\begin{array}{l}\text { 無色透明 } \\
\text { (無色透明) }\end{array}$ & $\begin{array}{l}\text { 無色 } \\
\text { 透明 }\end{array}$ & $\begin{array}{l}\text { 無色 } \\
\text { 透明 }\end{array}$ & 微黄色 & 微黄色 \\
\hline 透視度（cm） & $\begin{array}{c}50 \text { 以上 } \\
\text { (50以上) }\end{array}$ & 50以上 & 50以上 & 46 & 50 以上 \\
\hline 臭気 & $\begin{array}{c}\text { 土臭 } \\
\text { (土臭) }\end{array}$ & - & - & カビ臭 & 沼沢臭 \\
\hline $\mathrm{pH}(-)$ & $\begin{array}{c}4.9 \\
(7.0)\end{array}$ & 7.2 & 7.2 & 7.5 & 8.1 \\
\hline $\begin{array}{c}\text { 電気伝導率 } \\
(\mu \mathrm{S} / \mathrm{cm})\end{array}$ & $\begin{array}{c}26.6 \\
(88.9)\end{array}$ & 155 & 156 & 363 & 907 \\
\hline $\mathrm{TOC}(\mathrm{mg} / \mathrm{L})$ & $\begin{array}{c}1.37 \\
(3.88) \\
\end{array}$ & 3.64 & 1.78 & 9.95 & 13.8 \\
\hline $\operatorname{COD}(\mathrm{mg} / \mathrm{L})$ & $\begin{array}{c}0.57 \\
(17.7)\end{array}$ & 1. 18 & 0.64 & 6.85 & 2.28 \\
\hline $\mathrm{SS} \quad(\mathrm{mg} / \mathrm{L})$ & $\begin{array}{c}0.79 \\
(2.95)\end{array}$ & 1.12 & - & 2 & 3.97 \\
\hline $\begin{array}{l}\text { 一般細菌数 } \\
\text { (CFU } / \mathrm{mL})\end{array}$ & $\begin{array}{c}50 \\
(704) \\
\end{array}$ & 1200 & 151 & 420 & 8050 \\
\hline $\begin{array}{l}\text { 従属采養細菌 } \\
(\mathrm{CFU} / \mathrm{mL})\end{array}$ & $\begin{array}{l}3.5 \times 10^{5} \\
\left(1.5 \times 10^{7}\right) \\
\end{array}$ & $1.7 \times 10^{5}$ & 700 & $8.9 \times 10^{3}$ & $\begin{array}{c}5.3 \times \\
10^{4} \\
\end{array}$ \\
\hline $\begin{array}{l}\text { レジオネラ属菌 } \\
\text { (CFU/100mL) }\end{array}$ & $\begin{array}{c}\mathrm{ND} \\
\left(3.0 \times 10^{4}\right)\end{array}$ & 15 & ND & 68 & 62.5 \\
\hline $\begin{array}{l}\text { 大腸菌群 } \\
(\mathrm{CFU} / \mathrm{mL})\end{array}$ & $\begin{array}{c}\mathrm{ND} \\
(240)\end{array}$ & ND & ND & ND & 88 \\
\hline
\end{tabular}

注）（RUN6）：長期滞留雨水

表 6 各種用途水における高順（中央値 $\mathrm{n}=6 \sim 9$ ）

\begin{tabular}{|c|c|}
\hline 項目 & 高順 \\
\hline $\mathrm{pH}(-)$ & $\begin{array}{l}\text { 修景 }>\text { 浄化 }>\text { 一般浴槽 - 循環 }>\text { 雨水 } \\
\begin{array}{llll}(8.1) & (7.5) & (7.2) & (4.9)\end{array}\end{array}$ \\
\hline 電気伝導率 $(\mu \mathrm{S} / \mathrm{cm})$ & 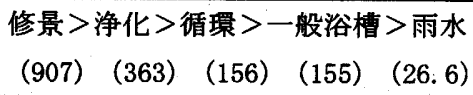 \\
\hline $\mathrm{TOC}(\mathrm{mg} / \mathrm{L})$ & $\begin{array}{l}\text { 修景 }>\text { 浄化 }>\text { 一般浴槽 }>\text { 循環 }>\text { 雨水 } \\
(13.8)(9.95)(3.64)(1.78)(1.37)\end{array}$ \\
\hline 一般細菌数（CFU/mL） & $\begin{array}{l}\text { 修景 > 一 般浴槽 }>\text { 浄化 > 循環 }>\text { 雨水 } \\
\begin{array}{lllll}(8050) & (1200) & (420) & (151) & (50)\end{array}\end{array}$ \\
\hline レジオネラ属菌（CFU/100mL） & $\begin{array}{l}\text { 浄化 }>\text { 修景 }>\text { 一般浴槽 > 循璦 - 雨水 } \\
\begin{array}{cccc}(68) & (62.5) & (15) & (\mathrm{ND})\end{array}\end{array}$ \\
\hline
\end{tabular}


化槽処理水は、中央值からみて p H 率.は $363 \mu \mathrm{S} / \mathrm{cm}$ であった。有機污濁物質を TOC および COD から 評価すると、TOCは $9.95 \mathrm{mg} / \mathrm{L} 、 \mathrm{COD}$ は $6.85 \mathrm{mg} / \mathrm{L}$ が示された。

次に一般細菌数は $420 \mathrm{CFU} / \mathrm{mL}$ を示し、従属栄養細菌は $8.9 \times$ $10^{3} \mathrm{CFU} / \mathrm{mL}$ が検出された。修景用水の $\mathrm{TOC}$ は $13.8 \mathrm{mg} / \mathrm{L}$ と最も高 く、一般細菌数も $8.05 \times 10^{3} \mathrm{CFU} / \mathrm{mL}$ が検出された。

得られた水質試験結果について雑用水としての水質評価を行った。 まず表 6 に示すとおり、対象試料水の TOC の中央值について高順に 並べてみると、修景用水 $(13.8 \mathrm{mg} / \mathrm{L})>$ 浄化槽処理水 $(9.95 \mathrm{mg} / \mathrm{L})$ $>$ 一般浴槽水 $(3.64 \mathrm{mg} / \mathrm{L})>$ 循環浴槽水 $(1.78 \mathrm{mg} / \mathrm{L})>$ 雨水 $(1.37$ $\mathrm{mg} / \mathrm{L})$ の順となり、有機污濁の進行程度がわかる。

TOC、一般細菌数および大腸菌群の中央值と使用用途別水質ラン ク（表 7）6，7）に基づき、表 8 に示す項目について対象試料水の水質 ランク付けを行った（表 8)。すなわち、AA は飲用として利用可能 となり、 $\mathrm{A}$ は洗浄水（旡房洗浄用）、 $\mathrm{B}$ は風呂・洗濯およびプール用 水、 $\mathrm{C}$ 親水用水、 $\mathrm{D}$ は洗車用水、そして $\mathrm{E}$ は水洗便所の洗浄水と しての使用用途と定義した。

各種用途水の水質ランクづけ評価結果を表 9 に示す。これより、 浄化槽処理水および一般家庭浴槽水は E にランクされ、循環浴槽水 はBとなった。

なお、雨水は酸性を示したことことから pH の調整は必要である が、 $\mathrm{AA} の$ 水質となることがわかる。これより、各種用途水の再利用 可能とされる使用用途は、一般家庭浴槽水、合併式浄化槽処理水お よび修景用水は水洗便所の洗浄水、循環浴槽水は風呂・洗濯およびプ 一ル用水、雨水は飲用可能な水質と同程度と評価することができる。 また、屋上緑化利用水も 3.1 の結果より、 $\mathrm{E}$ 判定となり水洗便所の 洗浄水としての利用が可能であると評価された。しかし各試料とも 従属栄養細菌等が検出されていることから、何らかの消毒方法によ り、細菌感染症リスクを考慮した使用方法が重要であると考えられ た。

\section{3 各種用途水における細菌リスク予測評洒}

本項では各種用途水中における増殖可能な細菌リスク予測評価を 行った。

\section{3.1 一般細菌の增殖特性}

図 4 にグルコースを基質とした条件下における一般細菌数の増殖 特性を示す。同図に示すとおり、TOC 浱度が 10 倍量高くなると一 般細菌数は $10^{5}$ 倍まで増殖することがわかる。なお、各浱度におけ る TOC は 50\%が減少した。

水中 TOC 濃度と増殖可能な一般細菌数の関係を図 5 に示す。さら に同図中に対象とした用途水中の実測 TOC を挿入し、対象用途水中 に増殖可能な一般細菌数を予測することを試みた。

同図に示すとおり、TOC 㳻度が 1.4〜 14mg/Lの篹囲において、ー 般細菌数は TOC 浱度の増加に伴い、対数的に増殖することが示され た。詳細にみると、TOC 银度が $14 \mathrm{mg} / \mathrm{L}$ と各用途水中で最も有機系 污濁の進行している修景用水は、107 $\mathrm{CFU} / \mathrm{mL}$ 程度まで一般細菌数 の増殖が予測された。

そして、最も有機系污濁の低い雨水においても、一般細菌数は $10^{3} \mathrm{CFU} / \mathrm{mL}$ 程度增殖する可能性が示された。

一方、一般細菌は増殖に伴い水中に白濁現象が認められる。そこ
表 7 各種用途水別水賽ランク 8)，9)

\begin{tabular}{|l|c|c|c|c|c|c|}
\hline \multicolumn{1}{|c|}{ 水質ランク } & $\mathrm{AA}$ & $\mathrm{A}$ & $\mathrm{B}$ & $\mathrm{C}$ & $\mathrm{D}$ & $\mathrm{E}$ \\
\hline \multicolumn{1}{|c|}{ 使用用途 } & 飲用 & 㞛房 & 風呂等 & 親水 & 散水 & 便所 \\
\hline $\mathrm{TOC}(\mathrm{mg} / \mathrm{L})$ & $<2$ & $<3$ & $<5$ & $<10$ & $<20$ & $<30$ \\
\hline 一般細菌数 $(\mathrm{CFU} / \mathrm{mL})$ & $<100$ & $<100$ & $<200$ & - & - & - \\
\hline 大腸菌群 $(\mathrm{CFU} / \mathrm{mL})$ & $\mathrm{ND}$ & $\mathrm{ND}$ & $\mathrm{ND}$ & $\mathrm{ND}$ & $\mathrm{ND}$ & $<10$ \\
\hline
\end{tabular}

表 8 各種用途水の 3 項目における水筫

\begin{tabular}{|l|c|c|c|}
\hline & TOC (mg/L) & $\begin{array}{c}\text { 一般細菌数 } \\
(\mathrm{CFU} / \mathrm{mL})\end{array}$ & $\begin{array}{c}\text { 大晹菌群 } \\
(\mathrm{CFU} / \mathrm{mL})\end{array}$ \\
\hline 修景用水 & 13.8 & $8.1 \times 10^{3}$ & 88 \\
\hline 浄化槽処理水 & 9.6 & $4.2 \times 10^{2}$ & $\mathrm{ND}$ \\
\hline 一般浴槽水 & 3.6 & $1.2 \times 10^{2}$ & $\mathrm{ND}$ \\
\hline 循環浴槽水 & 1.8 & $1.5 \times 10^{2}$ & $\mathrm{ND}$ \\
\hline 雨水 & 1.3 & 50 & $\mathrm{ND}$ \\
\hline
\end{tabular}

表 9 各種用途水の水䨳ランクつけ評価

\begin{tabular}{|l|c|c|}
\hline & 評価 & 可能な使用用途 \\
\hline 雨水 & $\mathrm{AA}$ & 飲用 \\
\hline 循環浴槽水 & $\mathrm{B}$ & 風呂、洗濯等 \\
\hline 一般浴槽水 & $\mathrm{E}$ & 便所 \\
\hline 浄化槽処理水 & $\mathrm{E}$ & 便所 \\
\hline 修景用水 & $\mathrm{E}$ & 便所 \\
\hline
\end{tabular}

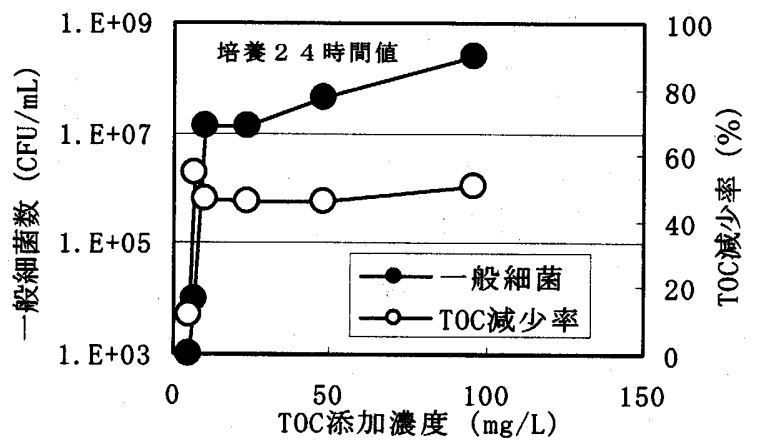

図 4 一般細菌の增殖と TOC 隇少率の一例

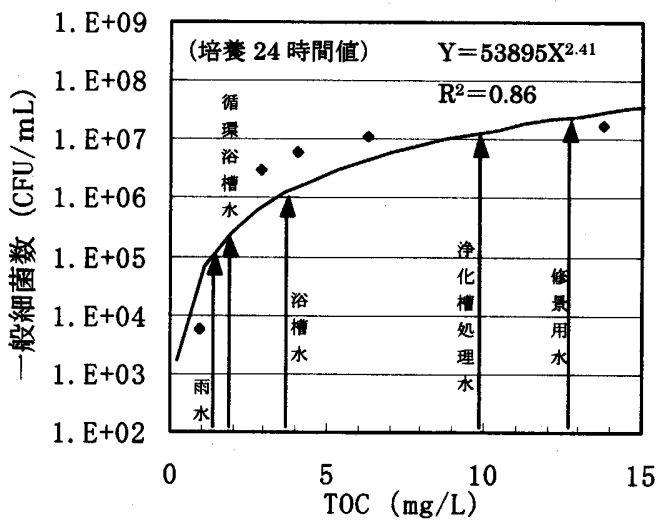

図 5 各種用途水における一般細蕃の增殖特性の予測 
で、増殖に伴う濁度を吸光度 $(\lambda=560 \mathrm{~nm})$ より評価 $\left.{ }^{8}\right)$ し、TOC 莀 度との関係を求め、図 6 に示す。

これより、一般細菌の增殖に伴う吸光度の上昇は、TOC 浱度の高 順にあり、24 時間が最大ピーク值となり、120 時閒までほほ平衡に あった。

図 7 では各 TOC 浱度条件下で示された吸光度値と一般細菌数の関 係を求めた。関係式は $\mathrm{G}=7 \mathrm{E}+11 \mathrm{~A}^{5.08}(\mathrm{G}:$ 一般細菌数 $(\mathrm{CFU} / \mathrm{mL}), \mathrm{A}$ : 吸光度 (一) , $\left.\mathrm{R}^{2}=0.85\right)$ が得られた。関係式より、たとえば、浄化 槽処理水中に増殖する一般細菌数を求めると $10^{7} \mathrm{CFU} / \mathrm{mL}$ となった。 以上の結果より、対象とする各種用途水の TOC 濃度から、增殖可 能な一般細菌数を求めると、TOC 洤度で $1.3 \mathrm{mg} / \mathrm{L}$ 以上が示されれ ば、一般細菌の增殖を伴う水質であることが予測された。

すなわち、比較的有機物湍度の低い各種用途水中において、細菌 が増殖することが明瞭であり、衛生学的な措直を施す重要性が示唆 された。

\subsection{2 レジオネラR菌の振とう培養法による增党試硂}

本実験では、TOC 濃度の異なる各種用途水中でレジオネラ属菌の 増殖がどのように推移するかを中心に検討した。なお、本実験では 植菌したレジオネラ属菌以外の細菌はろ過滅菌した。各種用途水中 の TOC とレジオネラ属菌の経日変化を図 8 に示す。

TOC 初濃度 $(1 \mathrm{mg} / \mathrm{L}$ 前後) が低い精製水および雨水中におけるレ ジオネラ属菌の増殖特性は、日数が経過するにつれ増殖する傾向に あり、初瀑度 $10^{2} \mathrm{CFU} / \mathrm{mL}$ の本菌は $10^{5} \mathrm{CFU} / \mathrm{mL}$ まで増殖した。

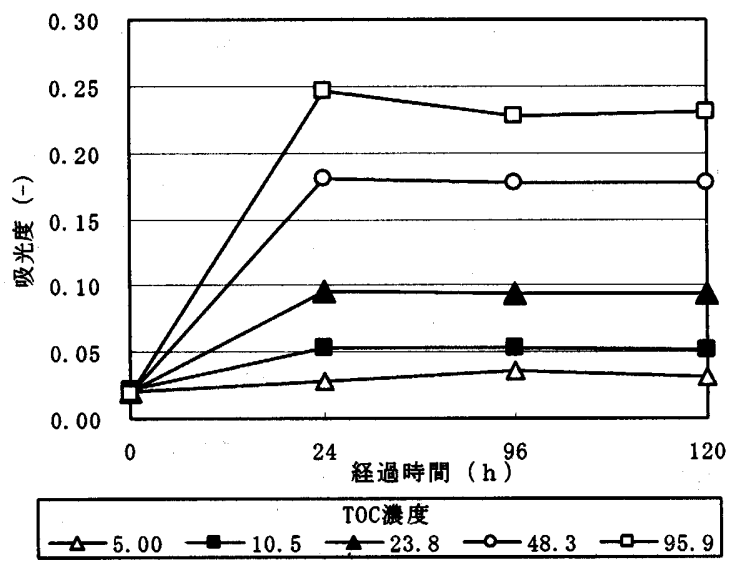

图 6 TOC 湱度による吸光度の経時変化

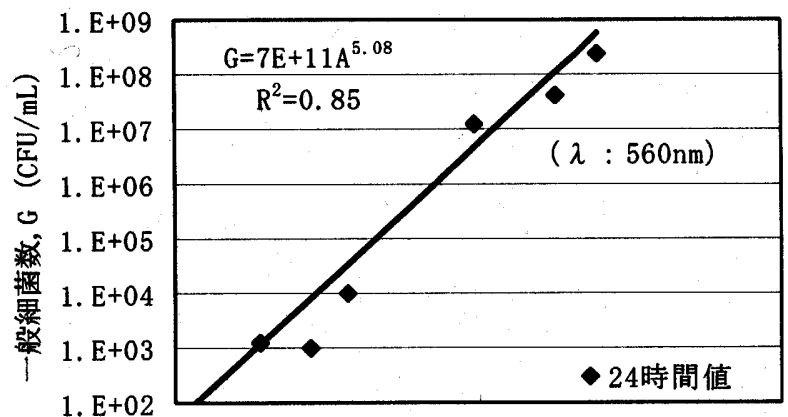

0.010

0.100

1.000

吸光度, A (-)

图 724 時間時における一般細菌数と吸光度の相関図
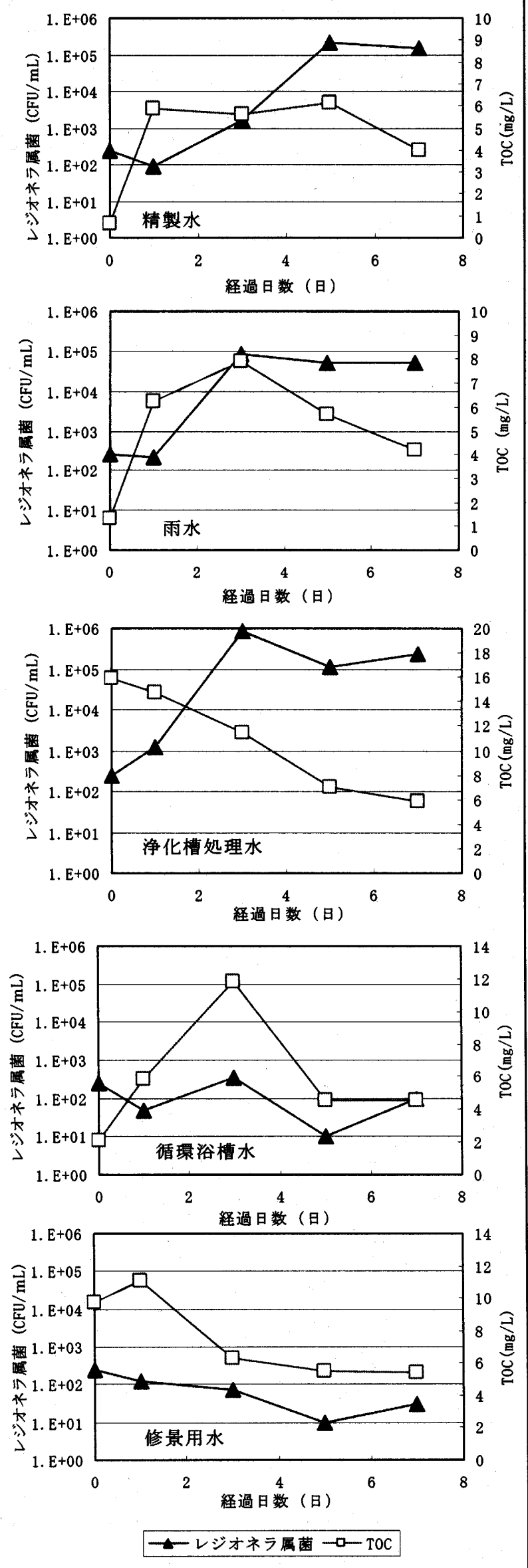

図 8 各種用途水におけるレジオネラ属菌と TOC の経時変化 
また、TOC 初浱度が $15 \mathrm{mg} / \mathrm{L}$ 前後を示す浄化槽処理水中における レジオネラ属菌も $10^{6} \mathrm{CFU} / \mathrm{mL}$ まで増殖した。

一方、レジオネラ属菌の增殖がみられなかった試料は、修景用水 および循環浴槽水であり、初港度 $10^{2} \mathrm{CFU} / \mathrm{mL}$ は $10 \sim 10^{2} \mathrm{CFU} / \mathrm{mL}$ になった。

以上の結果より、レジオネラ属菌は精製水および雨水のように有 機基質の低い環境下でも増殖可能であることがわかった。

\subsection{3 レジオネラ属菌の静思培基法による增殖試験}

3.3.2 の実験では、各種用途水中にレジオネラ属菌を植菌し、振と う培養法による増殖特性について検討した。

本実験では、試料中にレジオネラ属菌を植菌せずに、静置培養下 におけるレジオネラ属菌の増殖挙動について観察した。

図 9 に修景用水、一般浴槽水、循環浴槽水および給湯水の時間に伴 う TOC 変化を示す。TOC 初丕度は一般浴槽水が $12 \mathrm{mg} / \mathrm{L}$ と最も高 い値になった。これは、入浴者が浴槽内で体を洗い、浴槽水の TOC 濃度を高めるために意図的に行った結果である。給湯水および循環 浴槽水は $3 \mathrm{mg} / \mathrm{L}$ 前後の低い值を示した。TOC の時間的な推移をみる と各試料とも 1 週間前後はほほ平衡を示し、TOC 初䈨度が $12 \mathrm{mg} / \mathrm{L}$ と高い一般浴槽水は 9 日值で約 $40 \%$ 前後の TOC 減少がみられた。

同条件下における従属栄美細菌の增殖特性を図 10 に示す。同図よ り、実験開始時の細菌数をみると給湯水は不検出となり、その他の 試料は $10^{4} \mathrm{CFU} / \mathrm{ml}$ オーダーで検出された。

給湯水も 3 日間、 $25^{\circ} \mathrm{C}$ 下に静置すると $10^{4} \mathrm{CFU} / \mathrm{ml}$ まで従属栄盖 細菌は増殖することがわかる。その他の試料は測定期間中において $10^{4} \mathrm{CFU} / \mathrm{ml}$ と平衡を示した。

レジオネラ属菌の増殖特性を図 11 に示す。レジオネラ属菌の増殖 が最も顕著であった試料は一般浴槽水であり、入浴直後の試料中か らは $20 \mathrm{CFU} / 100 \mathrm{ml}$ が検出された。この試料を 3 日間静置すると、 レジオネラ属菌は $10^{4} \mathrm{CFU} / 100 \mathrm{ml}$ まで増殖した。一方、初期值は不 検出の給湯水も 9 日間滞留させると $100 \mathrm{CFU} / 100 \mathrm{ml}$ の増殖が示さ れた。また、家庭用循環浴槽水は生物ろ過槽により処理されている ため、静置培荃下においてレジオネラ属菌数が $10^{2} \mathrm{CFU} / \mathrm{ml}$ と増殖の 変動が小さい理由になったと考えられた。

表 10 に各培養条件下におけるレジオネラ属菌の生残率（最終培養 值）をまとめた。

同表に示すとおり、TOC 值の低い水質特性を示す雨水、給湯水お よび精製水中で本菌は $10^{2} \sim 10^{3}$ 倍で增殖し 10 日前後は生残するこ とが示された。

以上の結果より、雨水、給湯水および精製水などのように TOC 值 の低い水質であっても、滞留することでレジオネラ属菌は対数的に 增殖可能であることが明瞭に示されたことから、水循環利用におけ る細菌污染対策の重要性が示唆された。

\section{4. まとめ}

本研究では、屋上緑化システムにおける利用水の水質調査および 利用可能な各種用途水の水質評価を行い、本システムの有効な水利 用方法について検討した。得られた知見をまとめると次のとおりで ある。

（1）屋上緑化利用水の水質実態を知るために、有機污濁物質

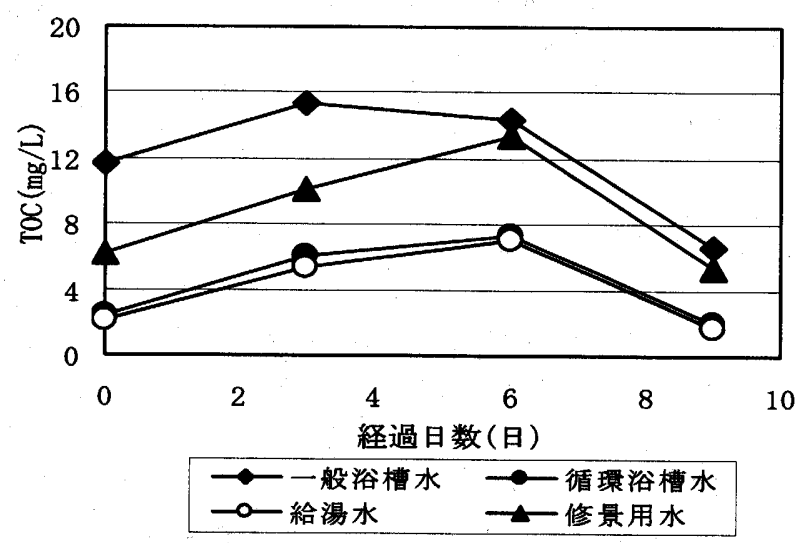

図 9 各種用途水における TOC の経時変化（静罿）

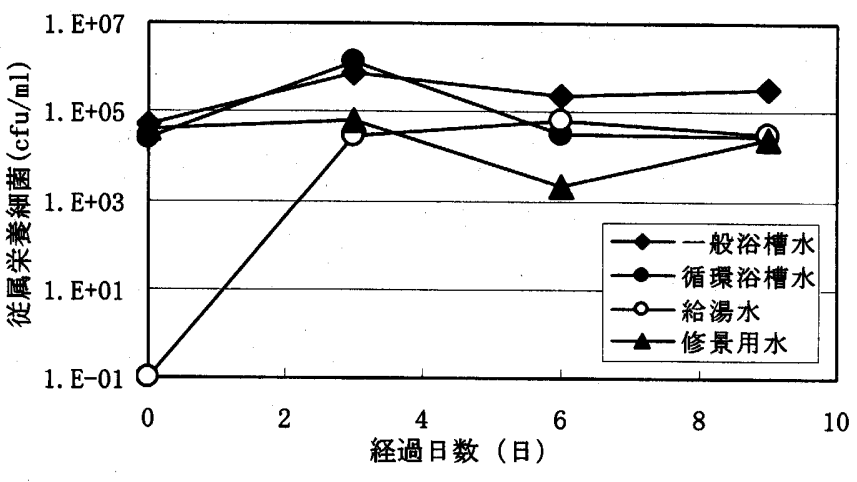

図 10 各種用途水中における従属栄美細菌の堌殖特性（静置）

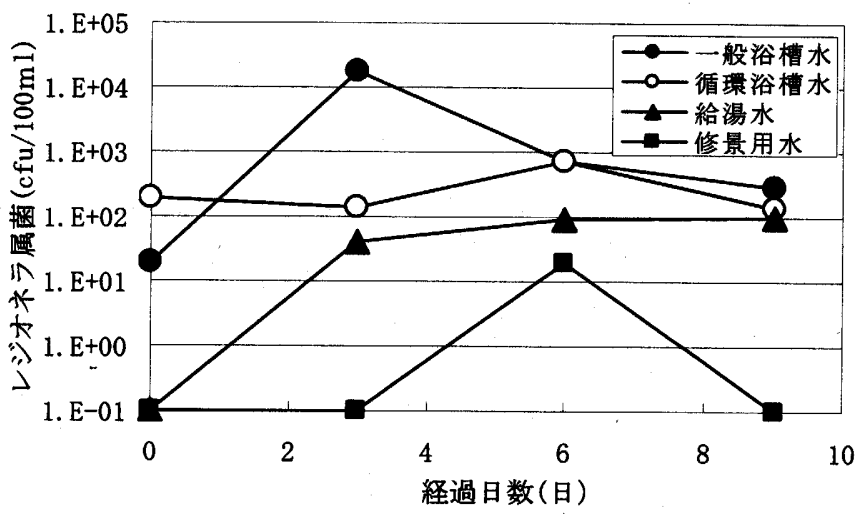

図 11 レジオネラ屈菌の增殖特性（静䰹）

表 10 レジオネラ屈菌の生残率と TOC 減少率

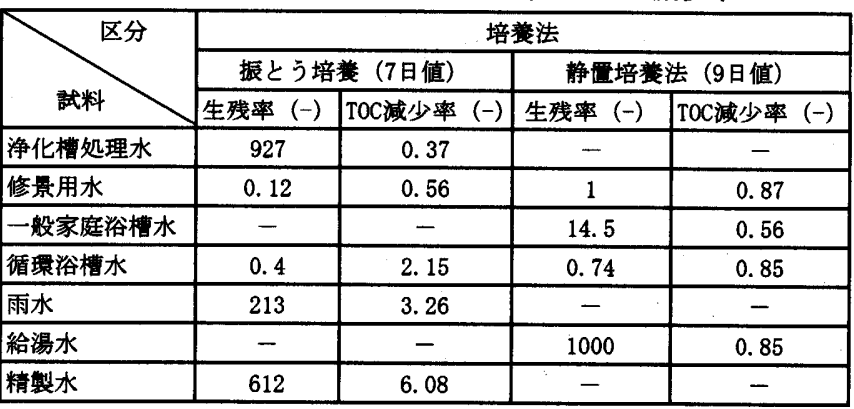

注）生残率 $(-)=$ 最終値/初期値 
(TOC,COD)、細菌類等を中心に測定を行った。その結果、67\% の施設（n=6）で水中有機污濁物質濃度は $10 \mathrm{mg} / \mathrm{L}$ 付近を示し た。

この理由として、貯留槽内における藻類による有機物の産生が 考えられた。同時に消化器系病原菌の指標細菌である一般細菌の 増殖も顕著であり、103〜104 $\mathrm{CFU} / \mathrm{mL}$ が検出された。

（2）本システムにおける雑用水の有効利用を目的として、各種用途 水の水質調查を行った。使用可能な用途を意識しながら水質ラン ク付けを行った結果、雨水、循環浴槽水の水中 TOC 值は $2 \mathrm{mg} / \mathrm{L}$ 以下であり、AA および B にランクされた。また、一般浴槽水、 浄化槽処理水、修景用水は $\mathrm{E}$ ランクとなった。

（3）雑用水を本システムに利用する際の細菌によるリスク予測評 価を行った。消化器系病原菌のリスクは一般細菌により評価した。

各種用途水中の水中 TOC 值加評価すると、修景用水 $>$ 浄化 槽処理水 $>$ 一般浴槽水 $>$ 循環浴槽水 $>$ 雨水の順に一般細菌数は 高くなることが予測された。

一方、呼吸器感染症の起因菌であるレジオネラ属菌のリスク 評価を行った結果、各種用途水のもつ基質に影響されずに、本菌 の増殖する可能性が示された。

（4）以上の結果より、本システムの衛生管理は、眝留槽内における 藻類の産生を防止するための措置を行い、細菌リスクを考虑した 消毒方法の検討、また植栽への散水はエアロゾルの飛沫を避けた 散水方法の潅水システム計画手法の確立について検討すること が今後必要とされる。

\section{謝辞}

本研究の一部は国土交通省総プロジェクト「自立偱環型住宅開発委員会[A9] 㗄源循環システム」の一環として行ったものである。関係各位に深甚なる謝意 を表する。その後の継続研究は、文部科学省学術フロンティア推進事業に選定 された「都市・建築のストック再生を目的とした環境共生技術の戦略的開発研 究」の一環で行ったものであることを付記する。実験にあたり、当時の卒業研 究生、椎野晃明氏（現：(株）カンドー）にご協カを賜りました。哚く感謝の 意を表します。

\section{参考文献}

1）大塚雅之,山海敏弘：资源循舆型住宅システムの開発 その 3 要素技術 と技術評価の概要, 日本建筑学会大会学術講演梗概集 D·1 分冊 pp.519-520,2004.8

2）中村伸也,野知啓子,椎野晃明,大塚雅之：瓷源循型住宅システムの開発 その 6 雨水・再利用水の水質評価，日本建築学会大会学術講演梗概集 D. 1 分冊 pp.525-526,2004.8

3）日本水道協会：上水試験法・解説,2001

4）光岡俊成：レジオネラ症を予防するために必要な措圈に関する技術上の 指針(厚生労做大臣告示)の制度について,空気調和・衛生工学,第 78 巻,第 2 号,pp63 69

5）椎野晃明,野知啓子,大塚雅之,山海敏弘他：屋上緑化システムに利用可能 な雑用水の水䜠調查,2003 年度日本建築学会関東支部研究報告集 I pp.535-538

6）山田筫次 : 建物内における上犋水,pp.20.25,1995

7）山本大輔：暮らしの水,pp25,1994

8）西村和之,真柄泰基 : 水の細菌增殖能力を用いた水啠評価,水啠污濁研 究, Vol 10,pp681 689, 1987 